Original Research Paper

\title{
Pendampingan Branding Packaging dan Digital Marketing pada Produk Umkm Keripik Talas di Lingkungan Bagek Longgek, Kelurahan Rakam
}

\author{
Ahmad jupri $^{1 *}$, Bayu herlembang ${ }^{2}$, M. Anggiri jauzy ariyansyah ${ }^{2}$, Baiq Yolanda Ika Anggari ${ }^{2}$, \\ Tapaul Rozi ${ }^{3}$, Eka S Prasdyai ${ }^{4}$ \\ ${ }^{1}$ Prodi Ilmu Lingkungan FMIPA Universitas Mataram \\ ${ }^{2}$ Fakultas Ekonomi dan Bisnis Universitas Mataram \\ ${ }^{3}$ Fakultas Peternakan Universitas Mataram \\ ${ }^{4}$ Prodi Biologi FMIPA Unversitas Mataram
}

https://doi.org/10.29303/jpmpi.v3i2.931

Sitasi: Jupri, A., Herlembang, B., Ariansyah, M. A. J., Anggari, B. Y. I., Rozi, T \& Prasdyai, E. S. (2021). Pendampingan Branding Packaging dan Digital Marketing pada Produk Umkm Keripik Talas di Lingkungan Bagek Longgek, Kelurahan Rakam. Jurnal Pengabdian Magister Pendidikan IPA, 4(3)

Article history

Received: 31 Juli 2021

Revised: 4 September 2021

Accepted: 7 September 2021

*Corresponding Author:

Ahmad jupri Prodi Ilmu

Lingkungan FMIPA

Universitas Mataram,

Indonesia

Email: juprizikril@gmail.com

\begin{abstract}
Abstrak: UMKM kripik talas romantis berdiri sejak tahun 2018. Olahan makanan yang diproduksi dan dihasilkan dan oleh UMKM ini adalah kripik yang berbahan dasar talas terdapat permasalah-permasalah yang dihadapi oleh pemilik antara lain yaitu pertama dalam pemasaran, karena pemasaran yang saya lakukan masih dari mulut ke mulut . Kedua, kemasan yang masih kurang menarik sehingga membuat konsumen jadi tidak tertarik dengan produk ini. KKN tematik unram 2021 membuat program yang berfokus pada olahan kripik talas ini, yaitu branding packaging yang bertujuan untuk semakin meningkatkan pejualan dan pemasaran. Melalui program ini dilakukan inovasi pada kemasan dan juga pada stiker produk. Kemudian dilakukan pendampingan digital marketing terhadap UMKM kripik talas dalam memanfaatkan media elektronik untuk dijadikan media promosi dan pemasaran
\end{abstract}

Kata kunci : Branding packaging. Inovasi. Media elektronik

\section{Pendahuluan}

Dalam sejarah perekonomian Indonesia, Usaha Mikro, Kecil, dan Menengah (UMKM) adalah penompang perekonomian bahkan dalam kondisi krisis sekalipun. Oleh karena itu, UMKM tersebar hampir di seluruh pelosok Indonesia. Salah satunyaUMKM juga terdapat di daerah Bagek Longgek, Kelurahan Rakam.Lingkungan Bagek Longgek Barat merupakan salah satu Lingkungan di Kelurahan Rakam, Kecamatan Selong, Kabupaten Lombok Timur. Lingkungan Bagek Longgek memiliki banyak produk UMKM mulai dari Bakso, Air Kangen Water, olahan makanan basah, Kerupuk, dan lain sebagainya. Pada UMKM Lingkungan Bagek Longgek barat beberapa memiliki kendala pada kegiatan branding, salah satunya pada kemasan di beberapa produk UMKM.
Dalam program kerja branding (packaging) milik mahasiswa Kuliah Kerja Nyata (KKN) Universitas Mataram (UNRAM) yang bertugas di Kelurahan Rakam, para mahasiswa tersebut membantu dalam mengatasi masalah-masalah yang dihadapi oleh UMKM terutama pada bagian kemasan.

Suatu produk makanan tidak terlepas dari suatu kemasan. Kemasan selain sebagai wadah produk juga sebagai daya tarik produk tersebut. Sehingga kemasan dari suatu produk dituntut untuk menarik dan kreatif dengan memadukan bentuk, warna, dan seni tulisan yang dilengkapi informasi produk agar dapat bersaing di pasaran. Branding merupakan suatu proses pembentukan nama, istilah, rancangan atau kombinasi dimaksudkan untuk mengidentifikasi barang atau jasa suatu kelompok penjual dengan membedanya dengan barang atau jasa kelompok lain. Menurutk otlet (2009), 
branding merupakan nama, istilah, tanda, simbol, rancangan atau kombinasi dari semuanya yang dimaksudkan untuk mengidentifikasi barang atau jasa atau kelompok penjual dengan untuk membedakannya dari barang atau jasa pesaing. Maka bisa dikatakan bahwa branding ini sebuuah tindakan komunikasi, memperkuat dan mempertahankan identitas sebuah brand produk penjual dalam mendapatkan perspektif kepada orang lain yang melihatnya.

Dalam temuan lapangan oleh kelompok mahasiswa KKN Tematik Unram 2021 terdapat UMKM yang begerak dibidang makanan yang terletak di Lingkungan Bagek Longgek Barat, Kelurahan Rakam, Kec. Selong, Kabupaten Lombok Timur. Produk tersebut adalah kipik talas. Olahan ini berbahan dasar dari talas lalu diberi bumbu-bumbu rahasia yang semakin meningkatkan cita rasa bagi setiap konsumenya. Namun UMKM yang memproduksi kripik talas masih terkendala dalam pengemasan dan juga bagian stiker produknya. Dikarenakan kemasan dan stiker yang seadanya dan sederhana membuat konsumen kurang berminat meliriknya dan juga kurang mengenali produk ini. Sehingga produksi kripik talas ini tidak jalan setiap hari, dikarenakan pemiliknya hanya memproduksi saat ada pemesanan. Dan konsumen yang memesan hanya berada disekitar lingkungan dan konsumen yang sama. Berangkat dari sisni mahasiswa KKN tematik unram 2021 melihat bahwa krpiki talas ini memeiliki potensi yang besar apabila dikelola dan dikembangkan lagi secara lebih professional. Sehingga KKN tematik unram 2021 membuat salah satu program kerja yang mengkhususkan pada produk kripik talas ini yaitu program branding packaging terhadap kripik talas. Diharapkan dengan Program kerja branding packaging ini, olahan kripik talas ini dapat menarik minat dan rasa penasaran konsumen-konsumen baru dan penjualanya dapat menjangkau pasar yang lebih luas dan menjangkau segala kalangan masyarakat.

\section{Metode}

1. Waktu dan tempat

Kegiatan Program branding packaging terhadap UMKM talas ini ini di mulai pada tanggal 24 juni 2021 sampai dengan agustus 2021 dilakukan di lingkungan bagek longgek barat, kelurahan rakam selong Lombok timur.
Kegiatan

Bentuk dari kegiatan ini merupakan sebuah tindakan untuk meningkatkan penjulan dan minat konsumen terhadap kripik talas melalui branding packaging terhardap produk UMKM kripik talas yang ada di kelurahan rakam. Dengan cara yaitu;

a. Pertama, mahasiswa KKN unram melakukan survey terhadap produk UMKM kripik talas

b. Kedua, mahasiswa KKN tematik Unnram melakukan kegiatan branding, mulai dari kemasan dan juga stiker terhadap produk UMKM kripik talas

c. Ketiga, mahasiswa KKN tematik melakukan memperkenalkan produk kripik talas pada media masa guna meningkatkan jangkaun pasar.

\section{Hasil dan Pembahasan}

UMKM kripik talas adalah UMKM yang tergabung dalam Kube (kelompok uasaha bersama) romantis, kube ini adalah salah satu kube yang dibentuk oleh kelurahan rakam sebagai bentuk bantuan dan dukungan kelurahan terhadap UMKM yang ada di kelurahan rakam. UMKM ini berdiri sejak tahun 2018 yang dimana didirikan oleh bapak samsul rizal.yang terletak di RT. 04, lingkungan bagek longgek barat, kelurahan rakam, kecamatan selong, kabupaten Lombok timur. Olahan makanan yang diproduksi dan dihasilkan dan oleh UMKM ini adalah kripik yang berbahan dasar talas. Awalnya UMKM kripik talas hanya dijadikan sebagai usaha sampingan oleh pak rizal sebagai pemiliknya dan juga istrinya, dikarenakan ia memiliki profesi dan kesibukan lain yaitu sebagi salah satu guru di paud dan juga salah satu madrasah.

Dalam temuan lapangan UMKM talas romantis awalnya memproduksi kripik talas masih dalam skala kecil, ini dikarenakan UMKM ini hanya menjadi usaha sampingan dan juga hanya memproduksi ketika ada pesanan dan juga acara-acara yang diselnggarakan oleh kelurahan saja. Setidaknya produksi kripik talas oleh UMKM ini juga terhambat dikarenakan terdapat 
permasalah-permasalah yang dihadapi oleh pemilik antara lain yaitu pertama dalam pemasaran, karena pemasaran yang saya lakukan masih dari mulut ke mulut. Kedua, kemasan yang masih kurang menarik sehingga membuat konsumen jadi tidak tertarik dengan produk ini.

Setidaknya keripik talas ini memiliki tiga rasa yang asli buatan sendiri yang menjadi cirri khusus dari UMKM ini, yaitu original, manis dan pedas manis. Dengan melihat tingginya potensi yang dimiliki oleh UMKM ini, KKN tematik unram 2021 membuat program yang berfokus pada olahan kripik talas ini, yaitu branding packaging yang bertujuan untuk semakin meningkatkan pejualan dan pemasaran produk olahan dari UMKM, dan juga mendampingi UMKM kripik talas ini dalam meanfaatkan media elektronik untuk dijadikan media promosi dan pemasaran.

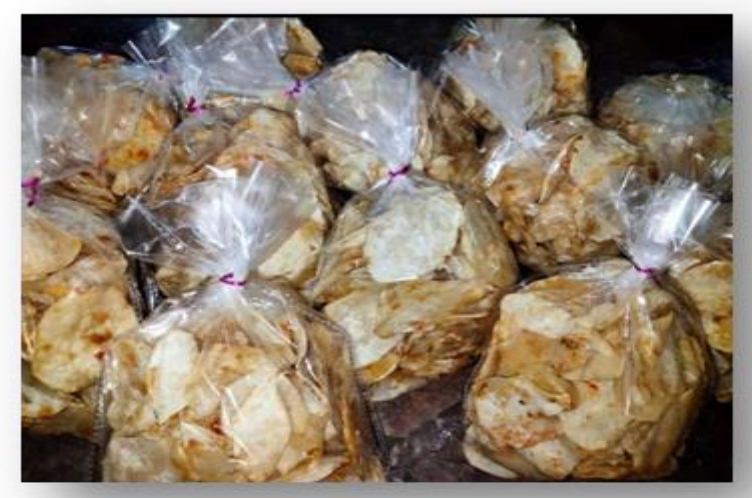

Gambar 1. Kemasan awal kripik talas

Sebagai langgkah awal, mahasiswa KKN Unram melakukan inovasi pada kemasan. Ini dilakukan karena kemasan awal yang digunakan oleh UMKM ini biasa saja sehingga minat dan juga rasa penasaran masyarakat sebagai konsumen baru berkurang dan kurang dilirik. Peran kemasan dimata konsumen mampu meningkatkan atau menurunkan penjualan suatu produk, Karena sesungguhnya tampilan kemasan yang menarik akan memberi kesan tersendiri bagi para konsumen dalam menentukan keputusannya untuk membeli atau tidak membeli suatu produk yang pada akhirnya tampilan kemasan yang sangat menarik bagi konsumen akan meningkatkan penjualan produk.

Untuk itu mahasiswa KKN tematik unram melakukan inovasi terhadap kemasan kripik talas, kemasan yang sebelumnya digangti menjadi kemasan standing pouch yang di desain dengan stiker dan logo terbaru. Kemasan standing pouch dipilih karena memiliki keamanan dan higenis, serta secara tampilan lebih menarik. Selain itu kemasan ini juga memiliki kekuatan dan anti lecet dari benturan sehingga keamanan dan ketahan produk lebih terjaga. Kemasan standing pouch juga menjaga produk dari pengaruh keadaan diluar kemasan sehingga bentuk, rasa, dan araoma dari produk tidak berubah sama sekali. Sehingga produk kripik talas memiliki ketahan yang jangka panjang.

Setelah melakukan perubahan pada bentuk kemasan, kemudian bentuk inovasi selanjutnya yang dilakukan terhadap produk kripik talas ini adalah, pembuatan stiker produk. Sebelumnya produk kripik talas ini tidak memiliki stiker dan nama yang melekat pada kemasanya, oleh karena itu produk kripik talas ini sulit dikenali oleh masyarakat luas. Inovasi pada stiker dilakukan karena stiker dapat menjadi media untuk menginformasikan produk. Mereka tidak menyadari kalau sticker dapat menjadi media iklan yang ampuh.

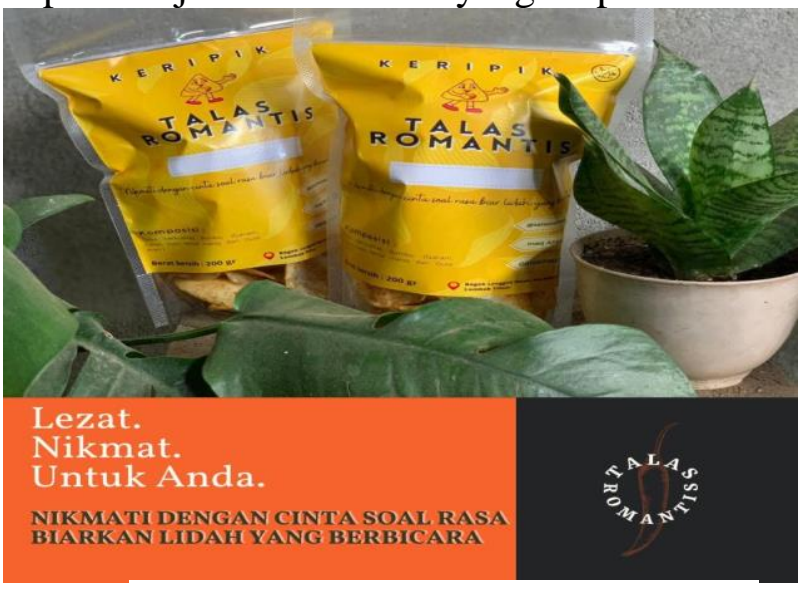

Gambar 2. Bentuk inovasi pada stiker 
Dengan penggunaan sticker dapat meningkatkan brand-awarness untuk produk kripik talas itu sendiri. Stiker pada produk kripik talas sendiri sendiri dapat mendeskripsikan kripik talas itu dengan tepat dan membantu membuat kripik talas ini lebih unggul dibandingkan dengan kompetitor yang lain. Selain itu dengan adanya stiker ini berfungsi dan bermanfaat besar dalam mempengaruhi masyarakat, oleh karena itu, dengan adanya stiker pada produknya, UMKM kripik talas dapat menjangakau pasar public dan konsumen yang lebih luas dan banyak.

Selain melakukan inovasi pada kemasan dan juga stiker pada produk UMKM kripk talas, yang sekaligus menjadi hambatan utama UMKM ini. Kemudian KKN rakam melakukan pendampingan terhadap terhadap UMKM kripik talas dalam memanfaatkan media elektronik sebagai media mempromosikan dan memasukan produknya. yang tentu saja sangat bermanfaat untuk UMKMny karena pada era saat ini kaum millenial lebih banyak menggunakan sosial media untuk membeli suatu barang dan makanan. Promosi kripik talas dengan menggunakan media internet dilatar belakangi oleh semakin banyaknya pengguna internet saat ini. Perkembangan teknologi mampu mengubah segalanya, tidak terkecuali dalam bidang bisnis. Namun, ini sangat memudahkan untuk memperlancar proses jual beli. Promosi sangat penting untuk perkembangan dan kesuksesan sebuah bisnis. Hal ini tidak lepas dari penggunaan media promosi yang tepat sehingga berdampak baik dan tepat sasaran. Pemanfaatan internet sebagai media promosi terhadap produk kripik talas memiliki berbagai keunggulan dibandingkan dengan media lainnya yaitu dapat dilakukan dimanapun dan kapanpun, biaya yang lebih murah, dan jangkauan yang lebih luas serta tidak terbatas. Bisnis online memiliki berbagai macam media jual beli dan promosi. Mulai dari website, media sosial hingga jejaring bisnis.

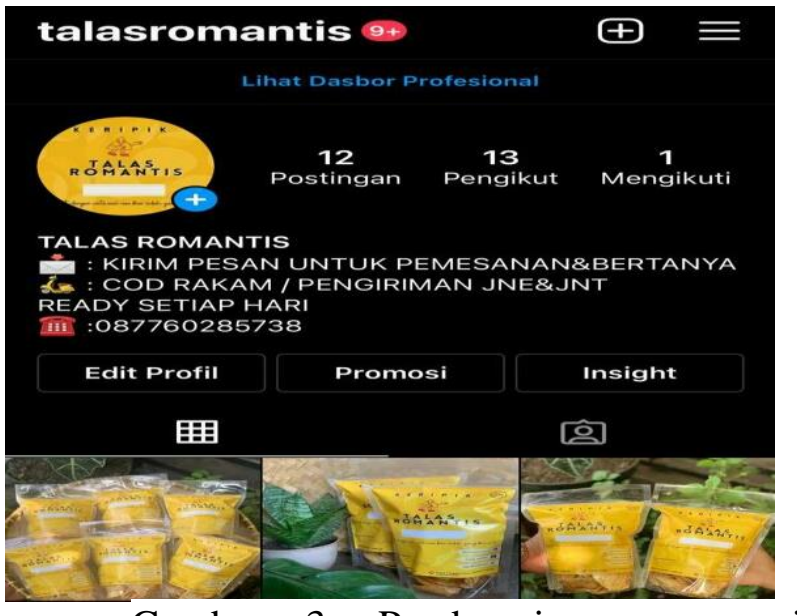

Gambar 3. Pendampingan promosi UMKM kripik talas di salah satu media masa

Inovasi yang dilakukan terhadap kemasan dan juga stiker produk kripik talas melalui program branding packaging ini bertujuan untuk semakin meningkatkan usaha UMKM kripik talas dalam memperkenalkan produk mereka dan juga dapat menjangkau pasar yang lebih luas dan diterima oleh semua kalangan. Tentunya dengan pembuatan kemasan untuk melindungi produk dari goresan atau cacat produk yang membuat produk menjadi rusak. Selain itu juga kemasan produk tidak hanya difungsikan pada saat proses pendistribusian barang dari pabrik ke distributor, namun juga melindungi produk ketika berada di toko-toko retail. Kemudian dengan adanya stiker baru membuat produk kripik talas lebih dikenal, menarik perhatian masyarakat luas dan membuat UMKM kripik talas lebih unggul dari kompetitor lainya. Kemudian dengan pemanfaatan media elektronik sebagai media promosi produk kripik talas diharapkan dapat lebih menjangkau pasar yang lebih luas dan juga bisa menyetuh kaum millenial lebih banyak menggunakan sosial media untuk membeli suatu barang dan makanan.

\section{Kesimpulan}

UMKM kripik talas romantis berdiri sejak tahun 2018 yang dimana didirikan oleh bapak samsul rizal.yang terletak di RT. 04, lingkungan 
bagek longgek barat, kelurahan rakam, kecamatan selong, kabupaten Lombok timur. Olahan makanan yang diproduksi dan dihasilkan dan oleh UMKM ini adalah kripik yang berbahan dasar talas. Namu dalam perjalananya UMKM ini terhambat dikarenakan terdapat permasalah-permasalah yang dihadapi oleh pemilik antara lain yaitu pertama dalam pemasaran, karena pemasaran yang saya lakukan masih dari mulut ke mulut. Kedua, kemasan yang masih kurang menarik sehingga membuat konsumen jadi tidak tertarik dengan produk ini. Dengan melihat tingginya potensi yang dimiliki oleh UMKM ini, KKN tematik unram 2021 membuat program yang berfokus pada olahan kripik talas ini, yaitu branding packaging yang bertujuan untuk semakin meningkatkan pejualan dan pemasaran produk olahan dari UMKM. Program branding packaging dilakukan mulai dari inovasi yang dilakukan pada kemasan, dimana kemasan yang dipilih adalah kemasan standing pouch. Kemasan standing pouch dipilih karena memiliki keamanan dan higenis, serta secara tampilan lebih menarik. Kemudian dilakukan inovasi pada stiker produk yang bertujuan meningkatkan brand-awarness untuk produk kripik talas itu sendiri dan juga mendampingi UMKM kripik talas ini dalam meanfaatkan media elektronik untuk dijadikan media promosi dan pemasaran.

\section{Daftar Pustaka}

https://koinworks.com/blog/promosi-usahamelalui-media-sosial/

http://bbkk.kemenperin.go.id/page/inovasikem asan.php

https://www.google.com/amp/s/www.simplidot $\underline{\text { s.com/packaging-produk/ }}$ 